though even there, where this connection is so clear, we should see at the same time how greatly the tops and sides of the long saddle-shaped arches of rock have suffered from subsequent waste. But among the contorted, inverted, and broken rocks of the Central Alps the task would be infinitely more difficult.

We could not advance far, however, in such a quest before observing that one feature stands out conspicuously enough among the mountains, viz., that whatever might have been their original outlines, these were most certainly not the same as those which we see to-day. No part of the history of the ground can be made more selfevident than that, since the birth of these mountains, millions upon millions of cubic yards of rock have been worn off their crests and ridges, and carved out of their sides. There is not a cliff, crag, or valley along the whole chain of the Alps which does not bear witness to this great truth.

If then, even when dealing with the young Alps, we cannot be quite sure what were their first or infant features, how impossible must it be to decide as to the early outlines of such immensely more ancient uplands as those which date from palæozoic times! For, evidently, the higher their antiquity, and the longer, therefore, their exposure to ceaseless waste, the more must these outlines be changed. The general mass of land might still remain land, but trenched and furrowed and worn down, as the Alps are now suffering, until not a single vestige or indication of its first contour survived, the remaining portions being, as it were, merely the stump or base of what once was.

Now this is the position in which the question presents itself in Britain. The hills of the Highlands and Southern Uplands of Scotland, of the Lake district, and of Wales, are not mountains in the same sense as the Alps or Pyrenees, or other great continental mountain-chains. However much these long lines of elevated ground may have had their outlines modified by the universal waste of the earth's surface, their linear character, the general parallelism of their component ridges, the undulations of the strata along their flanks, as well as their internal geological structure, bear witness to the fact that they are but huge wrinkles upon the shrivelled globe--tracts which have been thrust up while the neighbouring regions have sunk down. But in Britain these characteristic features are wanting. In all probability there never was any true mountain-chain in our region. There is good reason to believe that in very ancient times, that is to say, previous to the Old Red sandstone, a wide plateau-like mass of land was upraised on the north coast of Europe, surviving portions of it being represented by the detached hilly regions of Britain and the great table-land of Scandinavia. The rocks underlying this upheaved tract underwent, at the time of elevation, enormous compression and consequent contortion. This could not happen without an infirite amount of resistance. The heat thus evolved among the grinding masses may have been amply sufficient even to melt them in part. And no doubt it was during this process that they became crystalline over such wide areas, and were injected with granite and other melted products. But all this had been wholly, or almost wholly, completed before the time of the Old Red sandstone, for the deposits of that geological system are formed out of the older altered rocks, and lie undisturbed upon them. Even now, in spite of all the subsequent denudation, the patches of old red conglomerate which remain show to what an extent the older rocks had been buried under it, for they are found rising here and there to a height of 2,000 or $3,000 \mathrm{ft}$. above the sea. But they prove further, not only that the contortion of the underlying rocks preceded the Old Red sandstone, but that these rocks had suffered a vast extent of waste at the surface, before even the oldest visible parts of the conglomerate were deposited upon them. This waste bas been in progress ever since.
We need not, therefore, hope to discover any vestige of the aboriginal surface. A geological section drawn across any part of the hills proves beyond question that the general surface of the country has had hundreds or even thousands of feet of solid rock worn away from it. Such a section shows moreover that our present valleys are not mere folds due to underground movements, but are really trenches out of which the solid rock has been carried away.

So far, this is a question of simple fact, and not merely of opinion. The language of Hutton may be literally true of Britain :- "The mountains have been formed by the hollowing out of the valleys, and the valleys have been hollowed out by the attrition of hard materials coming from the mountains." Our British hills, unlike the chains of the Jura and the Alps, are simply irregular ridges depending for their shape and trend upon the directions taken by the separating valleys. The varying textures of the rocks, their arrangements with relation to each other, their foldings and fractures, and the other phenomena comprised under "what is termed "geological structure," have greatly modified this result, but the process has nevertheless, as I believe, been one of superficial sculpturing, and not of subterranean commotion and upheaval. On the details of this process it is not needful to dwell.

From these cursory statements, which express, I believe, the general concurrent opinions of the modern Huttonian school, it should be clear how far that school must be from ignoring the influence of subterranean forces. Hutton himself never did so, and his followers now know far more of these forces than he did. But on the other hand, they claim for the surface-agents in geology a potency great enough to cut down table-lands into mountain ridges and glens, to carve out the surface of the land into systems of valleys, and in the end to waste a continent down to the level of the sea.

$$
\text { (To be continued.) }
$$

\section{ASTRONOMY AT OXFORD}

D. DE LA RUE having, in the course of last summer, made a munificent offer of several astronomical instruments and apparatus, including a large reflecting telescope, to the University, the subject was brought under the consideration of the delegates of the Museum, who, at their first meeting in this term, appointed a committee to "report on the desirability of accepting the munificent offer of Dr. De La Rue to present to the University his celebrated reflecting telescope, on the probable cost of a tuilding to receive the instrument, and on the precise purposes for which this instrument may be usefully employed, in distinction to the refracting telescope now being set up."

The committee, after full and careful examination of the whole subject, have sent in a report, to which they have unanimously agreed, and which the delegates recommended, with entire confidence, to the favourable consideration of the council. In consequence of this report, the following forms of decree will be submitted to a convocation to be held on Thursday, Nov, 27 :-

1. That the reflecting telescope and other apparatus offered to the University by Dr. De La Rue be accepted; and that the Vice-Chancellor be requested to return the thanks of the University to Dr. De La Rue for his munificent gift. And that the curators of the University chest be authorised to pay to the delegates of the University Museum a sum not exceeding $1,500 l$, to be expended by them on the erection of buildings in the park suitable for the reception and use of the telescope and other apparatus presented by Dr. De La Rue, as also of the instruments at present in the small observatory on the east side of the museum, according to plans and specifications prepared by $\mathrm{Mr}$. Charles Barry, architect, and adjoining the observatory now nearly completed. 
2. That the curators of the University chest be authorised to pay annually to the Savilian Professor of Astronomy during five years, or until provision is made from some other source, the sum of $200 l$. for providing an some other source, the stant and defraying the expenses incurred in the assistant and and of the instruments in the observatory, an account of the expenditure of such sum to be annually submitted to the auditors of accounts.

We cannot doubt that Convocation will sanction a decre e which promises to make Oxford first in the field in this country in the power of aiding the new astronomy which is dawning upon us-thanks to the spectroscope and the application of photography.

Such a position may not be thought much of now, but in the coming time Oxford men will refer to it as one of the things of which Oxford has the greatest reason to be proud.

\section{NOTES}

Tre Copley Medal and the two Royal Medals in the gift of the Royal Society, have this year been awarded as follows:The Copley Medal to Prof. Helmholtz, the distinguished physiologist, physicist and mathematician, of Berlin; a Royal Medal to H. E. Roscoe, F.R.S., Professor of Chemistry in Owens Collcge, Manchester; and a Royal Medal to Dr. Allman, Pro. fessor of Biology in the University of Edinburgh.

Trre Annual Meeting of the Royal Society will be held on December $x$, when, after dining together, the Fellows will adjourn to their new apartments.

A. Deputation from the Council of the Society of Arts had an interview on Friday last with the Royal Commissioners of Scientific Instruction with reference to museums and galleries of science and art. The deputation consisted of Major-General F. Eardley-Wilmot, R.A., F.R.S. (Chairman of the Council), Mr. E. Chadwick, C.B., Colonel Croll, Mr. Hyde Clarke, the Rev. Septimus Hansard, Admiral Ommanney, C.B., F.R.S., Colonel Strange, F.R.S., Mr. Seymour Tewlon, with Mr. Le Neve Foster, Secretary. The Chairman of the Council stated that the object the Council had in view was to bring before, and ask the support of, the Commissioners to the action the society was now taking in reference to museums, and pointed out that this had special regard to the State giving increasing aid to existing museums, to aid in the multiplication of such museums, and rendering them available for educational purposes. He further pointed out the necessity for all such museums being placed under the control of a Cabinet Minister responsible to Parliament. He handed to the Commissioners a copy of resolutions embodying the views of the Council, stating at the same time that a large and influential committee was in the course of formation, and that a considerable number of members of both Houses of Parliament had already given in their names.

The first award of the Grand Walker prize of 1,000 dols. was voted by the Council of the Boston Society of Natural History on October I, to Alexander Agassiz, of Cambridge, U.S.A., for investigations on the embryology, structure, and geographical distribution of the Radiata, and especially of the Echinoderms, and the publication of the results as embodied in his recent work. The Annual Walker Prize of 60 dols. for 1873 was at the same meeting awarded to A. S. Packard for his essay on the development of the common house-fly. For the Annual Prize of I874, the subject is "The Comparative Structure of the Limbs of Birds and Reptiles." Memoirs offered for competition must be forwarded on or before April I, addressed to the Boston Society of Natural History, for the Committee of the Walker prizes, Boston, Mass., U.S.A., and each memoir must be accom- panied by a sealed envelope enclosing the author's name, and superscribed by a motto corresponding to one borne on the M.S.

IN the examination for Foundation Scholarships at Trinity College, Cambridge, to be held at Easter, 1874 , one or more Scholarships will be obtainable by proficiency in the Natural Sciences. The Examination in Natural Science will commence on Friday, April ro, and will include the subjects set forth in the regulations for the Natural Sciences Tripos. It will be open to all undergraduates of Cambridge or Oxford, and to persons not members of the Universities, provided that these last are under twenty years of age. Candidates who are not members of $\mathrm{Tr}$ inity College must sond their names to the Master, together with a certificate of age and good character, on or before Saturday, March 2 I.

We congratulate the University of Edinburgh on being the first in the United Kingdom to recognise the duty of universities so to frame their regulations for degrees in science as to encourage original work in opposition to mere book-knowledge. The University of Edinburgh has just issued a regulation that every candidate for the degree of Doctor of Science shall in future be required to submit a Thesis containing some original research on the subject of his intended examination, and that such thesis shall be approved before the candidate is allowed to proceed to examination.

Prof. Chevallier, for many years Professor of Mathematics and Astronomy in the University of Durham, died on the $4^{\text {th }}$ inst., at the age of 80 years.

We learn from Ocean Highuays that Prof. Mohn, of the Meteorological Institute at Christiania, and Mr. O. Sars are preparing a plan for the investigation of the sea between Norway, the Farö Islands, Iceland, and Spitzbergen, the expense of which will, it is expected, be defrayed by a grant of the Norwegian Storthing.

DR. RUDOLPHE WOLF has recently published in the Vierteljahr. schrift of the Zurich Society of Natural Science, the thirty-third number of his Astronomische Mittheilungen. The paper is important in reference to sun-spots chiefly, and as bringing out with great clearness the connection of these with variations in declina. tion of the magnetic needle. The author gives a series of daily observations of sun-spots, during: 1872 , made at Zurich, Peckeloh, Muinster, Palermo, and Athens. 'The mean relative number obtained is 101\%; and for the years $1866-72$ inclusive, the series runs thus :- $16{ }^{\prime} 3{ }_{\circ}^{8} 7^{\circ} 3$ (min. 1867 ), $377^{\prime} 3,73^{\circ} 9$, I $39^{\prime} \mathbf{I}$ (max. I870), III'2, IOI 7 . Dr. Wolf has constructed a formula by which the average yearly variations of magnetic declination, in a particular place, may be calculated from the relative sun-spot number (two constants for the place being given). In this way, for example, he obtains for Munich the quantity $10^{\prime} \cdot 80$ as representing the magnetic variation for 1872 ; the number got from observation is $\mathrm{IO}^{\prime} \cdot 75$, showing a close agreement. In the second portion of ] his paper Dr. Wolf discusses several points con. nected with the history of the telescope, the vernier, the pendulum clock, \&c. ; among other things, attributing to Bügi (who lived in the early part of the sixteenth century), a share in the discovery of the isochronism of the pendulum. The last portion of the paper reproduces some of the earlier sun-spot literature. The same number of Astronomische Nachrichten contains a note by M. von Asten, furnishing evidence against the supposed identity of a cometary object observed by Goldschmidt on May I6, I855, with Tempel's comet. (1867, II.)

THE recent meeting of the American Association for the Advancement of Science held at Portland, Maine, was considered on the whole a successful one. I57 papers were entered, and 